\title{
Complicating the Relationship
}

\section{Introduction}

Whereas New Zealand built the more comprehensive welfare state prior to World War I, the two regimes gradually converged on an incrementalist social policy model in the decades after the World War II. In an era characterised by prolonged economic growth, social protection as a whole underwent a process of testing. Would the welfare state continue to grow in two exceptionalist countries where, unlike Western Europe, employment relations was the central arm of social protection? As it turned out, not only was the welfare state incrementalist, but so were the arbitration system's decisions on wages. Decisions were often swayed by employers' arguments on their capacity to pay. As will be seen, this fuelled antiarbitration sentiment among key sections of the trade union movements of both countries.

The test was partially resolved from the late 1960s to the mid 1970s, when innovative movements in policy led to renewed interest in the welfare state. Notably, the phased implementation of formal equal pay for women and men workers also occurred in this era, and pressure on wagefixing continued into the early 1980s. However, the principal finding of 
this chapter is that, beneath these overarching similarities, social protection in New Zealand faced the more serious long-term challenges. Its arbitration system continued to suffer more fundamental downgrading in control over the wage-determination process. This had implications for social policy.

The relatively solid position of Australian arbitration, and arbitration's greater independence from government, were most easily seen in the system's closer ties with the trade union movement. The voluntary basis of unionism and the absence of national minimum labour standards legislation are also important considerations. In New Zealand, where few constitutional limitations were placed on the activities and policy capacities of government, there was increased government intervention within employment relations from the late 1960s onwards. The Australian arbitration system's greater authority was demonstrated most clearly in two phenomena: first, through equal pay provisions, which in Australia were channeled entirely through the Arbitration Commission, while in New Zealand direct government legislation was the delivery mechanism; and second, through the inability of the Australian government to impose incomes policies without the approval of the arbitration system.

The first two sections of this chapter examine respectively the key Australian and New Zealand developments in social protection from the late 1940 s to the early 1980 s. The third section provides a direct comparative analysis.

\section{Australia}

\section{Post-war Incrementalism: The Basic Wage and Social Security, 1950 to 1966}

Social protection during the post-war period in Australia was overridingly characterised by incremental improvements in wages and the benefits and services of the welfare state. Given the general improvement in economic conditions in Australia during the early post-war years-full employment having been achieved during the war-unions increased 
their strike activity and their demands for higher wages and lower hours of work (Turner 1976: 98-109). Despite incremental gains, however, the period spanning the end of the war to 1950 was not characterised by improvements in real terms.

As recommended by a government White Paper, Full Employment in Australia, economic policy generally prioritised full employment over the fight against inflation (Kewley 1973: 184-185). In the context of the emerging 'cold war', dissension between sections of the trade union movement exacerbated the situation. As well as seeking improvements in the employment relations sphere through applications to the Arbitration Court, 'moderate' unions, as opposed to communist-influenced unions, also sought welfare state augmentation (Gollan 1968: 40). The welfare state during this period was given reaffirmation by the Social Services Consolidation Act of 1947, which fused legislation on a wide range of benefits. The Act also liberalised eligibility for many benefits and increased their level. In the wages sphere, the 1950 decision represented a highly significant judgement in terms of social protection. In this 'mammoth' determination, the unions urged a return to the determination of the basic wage according to family needs. But this was rejected by the Court. In 1951 a claim was lodged by employers for a return to the 44-hour week, which met with a counter-claim by the unions for a 30-hour week. Both were rejected. A claim was also made in the following year by the metalworkers for increased margins, but this also failed (Hancock 1979: 151). Between 1951 and 1953 the Court exercised caution, the quarterly increments being the only major increases granted.

Change was in the air, however, as Australia was in the grip of high and accelerating inflation due to the Korean War boom and the rapid industrialisation associated with the growth in the manufacturing sector (Dyster and Meredith 1990: 198-218). Within this context, in 1953 the Court announced that the quarterly cost-of-living adjustments to the basic wage would cease, constituting the quintessential expression of the capacity to pay principle'. As a principle of wage determination, the needs of the family were effectively superseded by the ability of industry and the economy as a whole to sustain wage increases, which were assumed to be necessarily inflationary. Another major consideration in the decision was the existing structure of margins-including those related to skill, 
penalty rates, holiday-pay, annual leave and sick leave-and their relation to the basic wage. In other words, the Court made allowance for wage levels elsewhere across the economy (Dabscheck and Niland 1981: 316-317).

A 30-year era governed by the principle of determining movements in the basic wage according to the cost of living thus ended, and the capacityto-pay concept became the overriding wage-determinant until 1961, though in 1956 the practice of holding annual reviews of the economy was introduced. In 1954 a more centralised framework was adopted whereby the Court's rulings would determine the basic wage and margins, the latter mainly based upon the rates inherent within the metal trades. As well, the State-level arbitral tribunals were encouraged to adopt the principles of the federal system, encouraging a more effective flowon, on a national scale, of conditions determined by the Commonwealth arbitration system. In essence, this constituted the institutionalisation of the concept of 'comparative wage justice' (on which, see: Provis 1986; Isaac 1986).

An incremental approach also applied to social policy. After the development of a welfare state in the 1940s under Labor tutelage, the Menzies Liberal government of the 1950s and 1960s made steady but limited extensions. Yet, the Joint Parliamentary Committee on Social Security had given expression to a bi-partisan preference that the welfare state should be an important federal concern (Butlin et al. 1982: 197; Watts 1987: 61-83, 113-114). This preference was then institutionalised by the referendum of 1946, which handed the jurisdiction over most of the welfare state to the Commonwealth government. However, just as wage improvements in this period were granted largely on the basis of economic criteria, many welfare state reforms also tended to be determined with reference to market dictates (Carney and Hanks 1994: 39-41). Nowhere was this more evident than in the sphere of the Menzies health policy changes, where the government followed the explicit preference of the medical profession in adopting a mainly private health insurance model (Butlin et al. 1982: 218).

Though the health system was the most significant area of social policy to be extended before the late 1960s, the progressive liberalisation of the means-test on social security payments stands as an achievement (Carney 
and Hanks 1994: 39). Also, in 1958, supplementary benefits for pensioners paying rent were introduced. In 1961 the separate income and assets portions of the means-test were merged by imputing a notional income value on the assets subject to testing. In 1963 the married and single rates of pension were demarcated. In 1964, the child endowment was increased for third and subsequent children. In 1963, nursing home benefits were introduced, and in 1964, endowments for students over the age of 16 were brought in. Subsidies for costs associated with care of the aged had been introduced in 1954, and for those requiring sheltered workshops in 1963 (Carney and Hanks 1994: 39). Importantly, however, all of these measures did not alter the basis of state welfare in meanstested benefits funded from general revenue.

\section{The 'Rediscovery of Poverty', Equal Pay and the 'Total Wage', 1967 to 1974}

The late 1960 s to the mid 1970s was a period in which the central traditions of Australian social protection were ripe for challenge. The renewed interest in poverty from the 1960s was associated partly with the 'normal, incrementalist, process of policy review' over the decade (Castles 1985: 35). However, it was motivated more strongly by the growing concern, particularly in the United States and the United Kingdom, that poverty had re-emerged despite the growth of the welfare state after the war (Stewart 1995: 36-92; Townsend 1962, 1979). The first major inquiry into poverty in Australia, called People in Poverty: A Melbourne Survey, was conducted under the direction of R.F. Henderson of the Melbourne Institute of Applied Economic and Social Research. It first appeared in book form in 1966 (Henderson et al. 1970). Based upon an examination focused on the Victorian city of Melbourne, the study found that despite the generally high living standards of the city's people and the fully employed status of its labour-force, poverty was in existence.

The authors argued that, assuming the wife is not in employment, a family of four was in poverty if its income was less than the basic wage and the child endowment combined. It explicitly related poverty to the basic wage because of the importance that this concept had assumed 
historically to the determination of living standards, and also because of its comparability in function to welfare state payments in other countries (Henderson et al. 1970: 1). The study proposed that, where poverty was found, it was mainly caused by one of five identifiable 'disabilities': old age; unemployment; large families; recent migration to Australia; and prolonged illness. Yet the major recommendations did not involve a change in the underlying basis of social protection, the report arguing that it was within the realms of the existing social protection framework that the problem of poverty could be solved. The overriding policy prescription was to increase the rates of the major existing welfare state benefits: age, invalid and widows' pensions; sickness, unemployment and special benefits; and child endowment. In addition, recommendations were made for the wider provision of public housing, health insurance, and domiciliary services (Henderson et al. 1970: 191-198).

The Melbourne study was followed in 1972 by a national inquiry, established by the McMahon Liberal government, which reported just months before the dismissal of the Whitlam Labor Government in 1975. As part of its vision for more comprehensive social protection in Australia, however, the Whitlam government also established a Social Welfare Commission (Graycar 1979: 39-41), which had several briefs: to report on the needs of the community, and to make recommendations on the policy means by which these could be adequately fulfilled; to formulate 'a nationally integrated social welfare plan'; to advise the government on the costs of proposed social welfare programs, and to continuously review these; to examine and report on ways to provide relevant information and technical assistance to all organisations concerned with social welfare, whether at the level of the State, the local government or the voluntary sector.

The Commission which had the greatest potential to change the ethos of selectivity in welfare state provision, however, was the Commission of Inquiry into Poverty. Though its findings and recommendations were numerous, and its analysis wide-ranging (Mendelsohn 1979: 108), its single most relevant recommendation was for the adoption of a basic income scheme, or a 'guaranteed minimum income'. That is, as well as those 'reforms which can be made within the broad outlines of the 
existing social security system', the Commission urged the establishment of a social security system consisting of two basic elements:

(1) A set of regular payments to all citizens, called minimum income payments. These would be on the lines of the present child endowment, but much extended in scope.

(2) A proportional tax on all private income, without exception (Australia, Commission of Inquiry into Poverty 1975: 71).

Despite its potential for major change, however, as political history has shown, the year that the Commission's findings were published was the year that the Whitlam Labor government was dismissed. It cannot be stated with certainty whether its recommendations would have been implemented if Labor had retained office after the subsequent election. Overall, the period from the 'rediscovery of poverty' in the late 1960s to 1975-when it was made clear that Whitlam's proposals for a wholesale overhaul of social policy would be frustrated - saw modest reforms relative to what was on the agenda. Yet the Whitlam years did see a significant increase in expenditure on the services sector of the welfare state (Scotton 1978).

Several significant universalising elements were on the Labor government's agenda. Shortly after his party was elected, the new Minister for Social Security, Bill Hayden, announced that a guaranteed minimum income scheme was under consideration, and so was a national superannuation scheme (the Superannuation Inquiry, chaired by Hancock), a national accident compensation program, and a universal health care system. With such a package, the Social Security Minster, Bill Hayden, foreshadowed that 'Australia will have one of the best systems of social security in the world' (Lewis 1975: 3). Despite such high hopes, however, it was only the universal health scheme, called Medibank, which was implemented; though it was watered down by the subsequent government, the Coalition administration led by Malcom Fraser, and then resurrected as Medicare by the Hawke Labor government in the 1980s (see Chap. 5). Free university education was introduced in 1974 (Davey 1978), by which time the Commonwealth had assumed full responsibility for the financing of tertiary education. 
Apart from the significant increase in government expenditure on services, the main improvements made to the social security system included the abolition, in 1973, of the means-test on pensions for those aged 75 or more. In 1975 this was extended to those aged 70 and over, with a plan to eventually remove it for those aged 65 and over. Other measures included the upgrading of benefits as a proportion of average weekly earnings, and the introduction of a supporting mother's benefit (Carney and Hanks 1994: 42-43). Though universalist moves were made in the fields of education and health care, therefore, selectivity remained the main principle of social security benefit provision.

In the wages sphere, change had been effected by the gradual implementation of the equal pay principle. After a long history of advocacy for equal pay by feminists and some trade unions, dating back as early as the 1910s (Cass 1985; Lake 1992; Ryan and Conlon 1975), the Arbitration Commission awarded equal pay in 1969. The 'equal pay case', as it became known, occurred during the era of the 'total wage'. The departure from the basic wage and margins formula which the total wage represented had its roots in national wage cases from 1964 when the Court refused to adopt the concept, to 1967 when it accepted it, and 1968 when it implemented it (Laffer 1964; Hutson 1971: 62-106).

Though the total wage represented the Commission's attempt to regain control of wage determination processes, however, buoyancy in economic conditions enhanced the capacity of unions to gain wage increases in over-award pay. In short, up to the mid-1970s, the Commission argued that too many wage increases were occurring 'elsewhere in the economy' for the policy of the total wage to be effective as a means for controlling wages and their distribution across occupations and industries. Between 1967-68 and 1974-75, the percentage contributed by national wage cases to aggregate increases in male wages varied from a high of 52.6 percent to a low of 19.1 percent (Dabscheck and Niland 1981: 325). It was this factor which forced the Commission's rethink on the underlying basis of wages policy. It led to the abandonment of the total wage in favour of wage indexation.

In 1969, the Arbitration Court agreed to implement the principle of equal pay for equal work in four stages (Ryan and Conlon 1975: 145-175). By 1 October 1969 the female wage rate was to increase from 
75 percent of its male equivalent to 85 percent. By the 1 January 1970 it would be increased to 90 percent, by the same date in 1971 to 95 percent, and finally by the first day of 1972 the (official) male and female rates would be formally equal.

The significance of the equal pay principle for the Australia-New Zealand comparison is discussed further in the comparative section.

\section{From Reformism to Caution, 1975 to 1983}

From 1975, the reformist ethos engendered by the Whitlam government gave way to a combination of cautious enhancements in some areas of social protection, and retrograde steps in others. Caution was characteristic of the general policy strategy of the Fraser Liberal/Country Party Coalition government which was elected in 1975. Rhetorically, Fraser was wedded to a free market approach to policy. He prescribed a reduction in the size of government and a compression in the scope of its activities. In particular, the level and coverage of many welfare state policies appeared to be in line for cut-backs (Graycar 1979: 52).

There was a discrepancy, however, between the government's declarations and the policies it implemented. Though he supported economic liberalism, Fraser opposed free-marketeers within his party. Despite favouring the lowering of industry protection, he did not do so for fear of reprisal from some within the Country Party segment of the Coalition (Watts 1989: 105-113).

In the sphere of social security, contrary to what appeared to be a general policy of cut-backs, the record of the Fraser government is mixed. Among the positive measures was the removal of the property component of the means-test in 1976. Another was the introduction of the family allowances program, which subsumed the child endowment scheme introduced by the Menzies government in 1941, and income tax rebates for dependent children, effectively redistributing income to relatively disadvantaged families (Cass and Whiteford 1989: 286-288). In 1977 another significant advance was made with the extension of the supporting mothers' benefit to cover sole-fathers, the scheme being renamed the supporting parents' benefit (Cass 1983: 77-83). In 1978, 
the pegging of pension payments to the cost of living was written into legislation, though the income test was re-introduced on the indexation component of the pension for those beneficiaries aged 70 or more.

There were retrenchments and enhancements. In November 1975 the benefit rates for married and single unemployed people over 18 years of age were raised, though no such increase was given to single beneficiaries under 18. The indexation of benefits for those unmarried unemployed beneficiaries over 18 was withdrawn in 1978, and its real level fell by approximately 17 percent during the period of Fraser's reign despite some subsequent (non-indexed) increases. The level for under-18s fell by a greater proportion, approximately 46 percent. Eligibility criteria were also tightened significantly (Cass and Whiteford 1989: 294). Despite the attempts to reduce government expenditure on unemployment benefits, however, not only did a reduction not occur, but an increase eventuated, due mainly to a combination of increasing unemployment during the late 1970s and early 1980s and slight benefit liberalisations in 1980 and 1982 (Scotton 1978).

Indeed, though it sought to reduce aggregate real welfare expenditure, the Fraser government only reduced the rate of its growth, and then only between 1979 and 1981. As Watts (1989: 105-106) shows, as a percentage of both total government budget outlays and gross domestic product, the Fraser years were characterised by a general increase in welfare expenditure. The area in which real reductions in expenditure were successfully effected, however, was that of welfare services. In particular, health, housing, transport and urban development faced real cuts, the universal health care scheme, Medibank, being abolished and replaced by a more userpays-based system (Palmer 1989: 324-332; Watts 1989: 107).

In employment relations, the position of workers oscillated in response to changing economic conditions and the policies of the Arbitration Commission, as it began to be called. Viewing the experiment with the total wage as a failure because of its increasing lack of control over wage increases, the Commission adopted a new approach to wage determination, called 'wage indexation'. From April 1975, when the original wage indexation decision was handed down, the Commission began to grant wage increases quarterly, in line with movements in prices. After September 1978, increases were granted six-monthly. Under both 
systems, wage-increases were granted on the condition that wage movements outside of the indexation system be kept to a minimum. Between 1975 and 1981, the Commission was relatively successful in that indexed wage-increases constituted an average of approximately 90 percent of aggregate wage movements (Dabscheck 1994: 150-151).

Wage indexation was a continuous struggle for the Commission, however, as it relied heavily on each of the employment relations parties to converge upon the principle that wage deals outside the system should be minimised. In reality, some unions sought decentralised deals, and both the Fraser government and employers urged the Commission not to grant wage increases at all because of the industry's lack of capacity to pay them and the economy to sustain them (Dabscheck 1994: 151, 1989: 32). Yet, in the context of a short mining-led boom, some employers gave way and granted union claims outside of arbitration. There was also dissension within the government's ranks on wage determination, leading to the abandonment of wage indexation in July 1981. From then, a decentralised bargaining approach took effect. In 1982, a drought in Australia and an international recession combined to produce alarmingly high inflation and unemployment rates. In response, the Commission enforced a six-month wages-pause, which represented a return to centralisation, though this time without any consideration whatsoever of wage increases.

In short, for employment relations, the Fraser years were cautious at times and unstable at others. It is highly significant that in Australia it was the Arbitration Commission, and not the government, which had the constitutional capacity to impose incomes policies, of which the wages-pause was an example. A similar pause was also implemented in New Zealand, and at around the same time, though the government there faced no such legal limitations, and thus the pause was a government initiative.

This difference in the capacity of governments to directly make policy in employment relations is important to the comparative analysis between the two regimes, as the third section of the chapter reveals. 


\section{New Zealand}

Though the status of the arbitration system had varied from strong to precarious in previous eras, in the late 1940s the Arbitration Court was the most important mechanism regulating welfare (Davidson 1989: 161). But it faced testing by the end of the decade. Regardless of the level of commitment to arbitration, arbitration continued to hold implications for social policy.

\section{Renewed Testing of Arbitration: The Carpenters' and Waterfront Disputes, 1949-51}

After the war, New Zealand entered a period of corporatism in policy making (Sutch 1966: 358-359), and as a part of the deal between labour and the state, the wages share of gross domestic was decreasing. Finance Minister Walter Nash, leader of the Federation of Labour, F.P. Walsh, and Secretary of the Treasury, Ashwin, all worked alongside each other, managing to co-ordinate a wages policy of restraint. In return for the curtailment of wages income, social policy enhancements were used as a trade-off, a pacifier to trade unionists who otherwise would attempt to improve the conditions of their members by means of direct action against employers. The corporatist strategy was successful in that it effectively minimised the incidence of major strike activity (Chapman 1981: 352-359). However, the economic depression which was generally expected to occur after the war did not eventuate. Instead, general price increases for New Zealand's exports resulted in favourable balances of trade and an increase in the inflationary pressure which had formed during the war.

Many workers regarded the end of the war as an indication of better times for wages and conditions. The war effort had generally acted to decrease labour's share of gross domestic product and had effected changes in the traditional wage relativities based upon skill-differentials. Continuing labour shortages put trade unions wishing to step up their wage claims in a relatively strong position. As had occurred from 1912 to 1913, the climate was set for anti-arbitrationist unions to pose a serious 
challenge to the Arbitration Court's legitimacy. Before 1936, a tradesperson's margin for skill was 26 percent above the unskilled rate. By 1949 it was 14 percent (Sutch 1966: 354-355). In late-1948, the carpenters made a claim to the Court for the restoration of their lost margins. The Court refused the claim on the basis that it would create a precedent for other skilled workers.

Yet the vast majority of employers expressed their willingness in subsequent discussions to pay the carpenters the margins which they were seeking. The Carpenters' Union declared a 'go-slow' on jobs which the employers refused the union's claim for; that is, where the workers were paid only the minimum award rate and were subject to minimum award conditions. All 1500 members of the union, whether on a go-slow or not, were then locked out by their employers. The Federation of Labour, which was initially supportive of the striking workers, made a request to the union that it hand over the dispute; that is, allow the Federation to represent them in negotiations with the employers, the government and the Arbitration Court. The union refused to do so, with the knowledge that the Federation was opposed to the strike. The Minister of Labour then deregistered the union, and a replacement, arbitration-compliant union was formed (Sutch 1966: 354-358). The original union remained in existence for months, competing with the new union for members, though it was eventually rendered illegal. The Arbitration Act was amended so that an award could apply to a 'locality', rather than to the entirety of an industrial 'district', with its relevant union containing as few as 15 members. Compulsory unionism had thus been used against anti-arbitration unions, since the Minister of Labour could use the new authority to disarm them.

The corporatism of the latter years of Labour's first government proved unpopular with the voters in the 1949 election, and the National party formed government, with Sydney Holland as prime minister. The new government was 'basically a businessmen's and farmers' government' (Davidson 1989: 163). The Arbitration Court had operated alongside the interests of (the previous) government in administering wage restraint, and it had played a significant role in restricting the freedom of antiarbitrationist unions to agitate for higher remuneration; its role in suppressing the claims of the carpenters' union being a key demonstration of 
this. Many of the war-time stabilisation regulations, which the Labour government had kept until its election loss in 1949, were speedily removed by the Nationals. Though import and price controls were abolished, however, the wage determination regulations were not. Further, the 1950 amendment to the 1948 Economic Stabilisation Act gave the Arbitration Court the power to issue general wage orders and standard wage pronouncements, but dictated that decisions must pay regard to the economic ramifications of wage movements (Woods 1963: 172-173). The Arbitration Act was not designed to be an arm of economic policy as such, and so the wartime regulations seemed a more appropriate avenue within which to pursue what were perceived to be economically 'sensible' wage policies. This is different from the Australian situation, as discussed in the following chapter.

In 1950, in the context of rising prices-a symptom mainly of the Korean War boom and the government's relaxation of stabilisation subsidies on food products - the Arbitration Court was requested by the government to issue a general wage order. The order was issued by the Court in 1951, increasing wages by 15 percent, including an interim order of 5 percent which had been made the previous year. A number of groups of workers were excluded from this increase, however, and the Court exercised the power to do this under the amended Economic Stabilisation Act. One of the groups excluded was the waterside workers. The waterfront employers were only willing to grant their employees a 9 percent increase, and not 15 percent. This prompted the dockworkers, the 'watersiders', to initiate a 'full-scale industrial battle, the longest, costliest and most widespread in New Zealand's history' (Scott 1952, in Bassett 1971: 11). The New Zealand Waterside Workers' Union had combined with the Freezing Workers and other unions to withdraw from the pro-arbitrationist Federation of Labour in the previous year, forming the New Zealand Trade Union Congress (Roth 1986). Providing another instance of relative disunity within the New Zealand trade union movement, the Trade Union Congress threatened the monopoly with respect to peak union representation enjoyed by the Federation of Labour. Apart from this, however, it also upset the corporatist ethos within which wages policy was formulated (Davidson 1989: 163). 
The opportunity for all interests opposed to the anti-arbitrationist unions in the Trade Union Congress to challenge the watersiders came in 1951. At that time the industry's workers were locked out for their refusal to work overtime after objecting to the size their wage increment. Those opposing the Congress included the government, the Arbitration Court, the Federation of Labour, the farmers and the employers. The waterfront dispute is well documented (Bassett 1971). In the 151 days of the dispute, involving 22,000 workers, emergency regulations were formulated and armed troops were called in to guard the docks and handle cargo. Approximately a month later, the Trade Union Congress was crushed by an alliance between the government and the Federation of Labour; Walsh and Prime Minister Holland being instrumental. Soon after the end of the dispute, Holland rapidly called an election, which the Nationals won by an increased majority on the last election. The dispute saw the watersiders convincingly defeated, their conditions diluted significantly, and production re-organised according to managerial prerogative.

\section{The Weakening of Arbitration, and Social Policy Stagnation, 1951-67}

Through the 1951 amendments to the Arbitration Act and the Police Offences Act, the New Zealand government discouraged unions from operating outside of the arbitration system. It seemed on the surface as if the government, in combination with the Federation of Labour, placed arbitration as the centrepiece of employment relations. Yet, for the next 17 years, in the context of labour scarcity due to a long economic boom, New Zealand experienced the decline of arbitration as a mechanism for setting wages and other conditions of work (Walsh 1984, 1993: 180-182). In short, there was a trend of decentralisation. Despite this, the Arbitration Court continued to provide a floor of minimum labour standards, even if, in contrast to Australia, that floor was in addition to legislated minima (Brosnan and Rea 1991).

With respect to social policy, as in Australia, the period spanning 1950 s and 1960s was one of relative stagnation. It mainly contained 'incremental tinkerings', with no increase in real welfare expenditure. 
More importantly, though most social security benefit rates increased more rapidly than prices, they did not rise as quickly as real wages (Rudd 1993: 228-229). The most significant innovations included the extension of the widows' benefit to deserted wives after divorce in some cases in 1954, and the introduction in 1955 of an age benefit for women over the age of 55 (Hanson 1980: 117-132). The most noteworthy retrograde step, taken in 1951, was the use of the 'supplementary assistance' category in social security provision. The Social Security Act of 1938 had allowed for certain categories of people to receive supplementary assistance in emergency or exceptional circumstances if they did not qualify for a benefit, Pacific Islanders and refugees being two examples. In 1951, however, with the rising cost of living, rather than raising benefits accordingly, the supplementary assistance principle was used as a 'top-up' for existing beneficiaries, and a Supplementary Assistance Fund was set up specifically for that purpose. This impacted on sole-parents and old-age pensioners in particular, whose living standards were being eroded significantly (Sutch 1971: 75-79, 1966: 410-411).

Industrially, more decentralised deals were being made between unions and employers. And if employers and the relevant unions together agreed to jettison compulsory unionism clauses, they now could do so legally as the government abolished statutory compulsory unionism. Despite the abolition of statutory compulsion, however, unionism was still effectively compulsory in most cases, mainly because the labour scarcity of the 1950s gave unions more control over their conditions, and they could insist that their employer adhere to the compulsory model (Walsh 1984). However, the Federation of Labour was still angered, and it sought to remove its promise to operate exclusively within the arbitration system. Direct decentralised union bargaining with employers, and in some cases, direct action against employers, was the result (Deeks et al. 1978: 46).

In July 1962 the Court issued a general wage order which excluded dairy workers, shearers and other farm-workers from a 2.5 percent wage increase. That year saw the greatest number of strikes and the largest number of working days lost to industrial stoppages since 1951 (Walsh 1994: 179, 1993: 181) as the Federation of Labour conducted a series of industrial campaigns, including a threatened nation-wide waterfront stoppage. By 1963 the Arbitration Court had been placed under 
significant pressure to respond to a growing gap between the wage increases gained by the stronger unions, and the weaker unions who were more reliant upon increases granted by the Court. The differential between the so-called ruling rates and award rates grew by over 20 percent between 1947 and mid-1965 (Deeks et al. 1978: 46-47). The Court therefore faced growing pressure to respond. It did so, in 1968, by issuing a nil wage order. The implications of this are discussed below.

\section{Renewed Interest in Social Policy, Equal Pay, and the Restructuring of Employment Relations, 1968 to 1983}

As was the case in Australia, despite the stagnation in the welfare state which characterised the 1950s and 1960s, the late 1960s saw a renewed interest in social policy. A series of government-sponsored inquiries into the nature and effectiveness of the welfare state were established (Castles 1985: 35-38; Davidson 1989: 299-302). Easton (1981: 12) identifies 1967 as the year which marked the regeneration of government commitment to social policy innovation. In that year, the Taxation Review Committee reported, making a recommendation that social security benefits be increased. Its recommendations were not implemented.

In the same year, the Royal Commission of Inquiry upon Workers' Compensation released its report, entitled Compensation for Personal Injury in New Zealand. Its overriding recommendation was that the basis of existing workers' compensation policy-the principle that the party which causes the injury is liable for the compensation of the injuredshould be replaced by a comprehensive, earnings-related compensation system administered by an Accident Compensation Commission, funded by employers, the self-employed and motor vehicle owners. The new system was implemented in April 1974, after being extended in 1973 such that its benefits could be claimed by housewives and non-wage earners as well as workers (Davidson 1989: 301). It was thus universal and social insurance-based, and in these respects, a significant departure from traditional social policy in New Zealand. 
In terms of the potential to alter the existing basis of social security provision, however, the most significant inquiry was the Royal Commission on Social Security, set up in 1969, reporting eight months before the election of Labour to government in 1972 (New Zealand, Royal Commission on Social Security 1972). The report, Social Security in New Zealand, represented the first major evaluation of the social security system since 1938. Despite the capacity of the Commission to change the pattern of provision, or its funding base, it did not, and a switch to an earnings-related benefit system was rejected.

A minimum income scheme, as had been recommended by the Henderson Report in Australia, was rejected, mainly on the ground that it denied the diversity of circumstances of individual beneficiaries (New Zealand, Royal Commission on Social Security 1972: 162). A wholesale change to social security being foregone, therefore, the substantive amendments recommended by the Commission related mainly to the increase in the level of many existing benefits, including the family benefit, general medical services benefits, pensions, sickness, invalid and related benefits, unemployment benefits, and some specialist medical benefits (Davidson 1989: 299-301). Most of the Commission's recommendations were implemented.

The Commission on Equal Pay, which reported in 1971, also held the possibility of regime-change. As in Australia, the case for equal pay had been put to the Arbitration Court long before the principle of genderbased wage-equality was officially approved in 1972, and the drift toward its achievement was slow (Du Plessis 1993: 210-217; Dann 1985: 65-79). Importantly, and in contrast to the Australian case, the implementation of equal pay was implemented by the government, not the arbitration system.

In the public sector, equal pay had been implemented in 1965 through the Government Service Equal Pay Act of 1960. The Equal Pay Commission was established, reporting in the same year, its brief having been to decide on the most appropriate means by which equal pay could be implemented in the private sector. All submissions received by the Commission recommended that equal pay be implemented by the legislature, and outside of the arbitration system (Nieuwenhuysen and Hicks 1975: 94). It was decided that the most appropriate approach to implementation was 
gradualism, as in Australia. The Equal Pay Act of 1972 set out five equal, annual steps towards the implementation of equal pay.

The Act would become fully effective in 1977 , by which time social security innovations had proceeded considerably more rapidly, and representing considerably more far-reaching change than had been the case in the 1950s and 1960s. Change in the social security area had been inspired mainly by the various inquiries of the late 1960s and early 1970s, particularly the Royal Commission on Social Security. Among the most influential reforms implemented were the introduction of the Domestic Purposes Benefit and the Superannuation scheme. Under the first of these, either parent was eligible for a categorical, comprehensive benefit, whether or not they left their wife or husband voluntarily, or whether their husband or wife deserted them or died. Previously, many of them were only eligible for supplementary assistance.

The contest over superannuation between the National and Labour Parties resulted in a universally provided benefit. In 1974 the Labour government passed the New Zealand Superannuation Act. Superannuation was to be funded by employee contributions of 4 percent of earnings, and similar employer contributions. After the 1975 election, however, the scheme was halted by the new National government, and replaced by a universal, tax-funded, flat-rate benefit payable to over-60s (Bassett 1971: 300). The National government, which ruled from 1975 to 1984 , then further consolidated and extended social security, though the system remained within the largely selectivist framework laid out by the 1938 Social Security Act.

Though the welfare state did not provide the basis for major change in the way social protection was delivered historically, the arbitration system appeared as if it would be the basis for the regime-change. The period from 1968 to 1984 is characterised by efforts on the part of New Zealand governments to gain control of employment relations by means of increased use of non-arbitral legislation, though in some cases with the same or similar effects as arbitration. Such legislation included the General Wage Orders Act of 1969, which reformed the wage orders system. The Arbitration Amendment Act of 1970 and the Industrial Relations Act of 1973 reflected attempts by the government to restore the primacy of awards and establish a more orderly relationship between awards and 
above-award bargaining arrangements. In addition, from 1971, statutory incomes policies were imposed and various tribunals were created with the purpose of re-creating the Arbitration Court under different guises (Walsh 1984, 1993: 182-184). As will be seen in the next chapter, the overall impact of the developments of this period was to set the conditions for the eventual abolition of the compulsory arbitration system's role in providing social protection.

From 1971, when the government sought to rein-in wage claims by instituting statutory incomes policies, until the 1980s, employment relations was characterised by instability as neither the Arbitration Court nor the government could enforce stability. Strike levels increased at the beginning and again at the end of the 1970s. In 1979-80 there was a general strike. In June 1982 the government imposed a price- and wagefreeze, which lasted until 1984. The wage-freeze was governmentimposed. The Australian freeze, by contrast, was implemented only through the Arbitration Commission's approval of the government's wishes.

Substantively, however, it was a wage-freeze which faced both the New Zealand and Australian Labo(u)r governments upon entering office, the former in 1984 and the latter in 1983.

\section{Comparative Analysis}

Most of the detailed comparative policy scholarship on Australia and New Zealand has focused on the 1980s and 1990s. There is also some work on the period since the 1990s. This is justifiable, as will be discussed further in Chap. 5, but it is important to note here that the institutional and political legacies of more recent decades were either set or solidified in the four decades after World War II. This is the main source of the importance of the current chapter. 


\section{Who Has Said What?}

It is assumed within the multi-country or large- $\mathrm{N}$ comparative literature that the post-war period is the one in which the Australian and New Zealand regimes took their characteristic form (Esping-Andersen 1990; Macnicol 1992; Gauthier 1996; Castles and Mitchell 1992, 1993; Shaver 1990; Taylor-Gooby 1991). Esping-Andersen's (1990: 68) depiction of Australia and New Zealand as 'liberal' welfare states, for example, treats the two regimes as welfare state laggards during the period, largely on the basis that their union movements were able to gain benefits for workers earlier than those of most other nations, thus luring social protection more into the wages sphere than the welfare state. In this sense EspingAndersen and Castles (1985) are united in their narratives:

Australia and New Zealand constitute two cases in which the labor movements, despite being powerful, never fully embraced the universalist ideal. In these countries, labor retained the traditionally widespread preference for targeted income-tested benefits because they appear more redistributive. But the main reason seems to be the outstanding bargaining situation enjoyed by the trade unions for decades. Thus, as Castles (1986 [sic]) argues, labor's demands for social protection could be equally, if not better, served via wage negotiations. (Esping-Andersen's 1990: 68)

Similarly, corporatist analyses tended to view Australia and New Zealand during the period as having established an important place for centralised bargaining in the form of compulsory arbitration in the employment relations system (Calmfors and Driffill 1988; Bruno and Sachs 1985; Freeman 1988). This is despite the waning influence of arbitration during various periods already covered in this and the previous chapter. Freeman (1988, especially: 69-70), for example, argues that similar labour market institutions in Australia and New Zealand during the 1970s and early 1980s led the two nations to similar economic performance outcomes. Similarly, Calmfors and Driffill (1988: 17) argue that the 'intermediate' level of bargaining centralisation in both Australia and New Zealand during the 1960s and 1970s led them to economic outcomes which, from an international viewpoint, were highly similar. 
Though these comparative accounts help to contextualise the Australian and New Zealand regimes internationally, they are limited in their contribution to an understanding of the differences between the two regimes. Though these differences had not yet resolved themselves fully into a major policy bifurcation, the seeds of the more weighty divergence which was to occur in the 1980s and 1990s were sown. The direct or small-N comparisons of the two employment relations systems do provide partial explanations for the divergence in the post-war period (Brosnan et al. 1992; Bray and Walsh 1993, 1995; Bray and Haworth 1993; Sandlant 1988, 1989; Wailes 1997). The most helpful of these accounts is that of Bray and Walsh (1995). In discussing the two regimes in the post-war period, they argue:

[i] $\mathrm{n}$ both Australia and New Zealand, the system of arbitration by state tribunals gave rise to a complex but largely centralised collective bargaining system ... which in principle offered a potential base for corporatism; that is, the very wide scope of collective bargaining coverage in both systems met one precondition for corporatism. Coverage varied over time, but in the postwar period was not usually less than two-thirds of the workforce ... whilst the employment conditions of many other employees were heavily influenced by award negotiations. (Bray and Walsh 1995: 9-10)

To be sure, Bray and Walsh do identify the New Zealand arbitration system's more marked decrease in control over the wages system during the 1970 s to the early 1980s. However, given that their concentration is on the 1980s and 1990s, understandably they do not cover in detail factors which may explain the differences which occurred during the 1960 s and 1970s.

Sandlant (1989: 57-58) provides a more comprehensive account of the differences between the Australian and New Zealand employment relations systems during the post-war period. Like Bray and Walsh (1993, 1995), he concentrates on developments after the early 1980s, in expounding the key post-war factors shaping the establishment of corporatism in Australia and its rejection in New Zealand. However, he places great importance in the relative centrality of the arbitration system in Australia. This centrality stemmed mainly from the greater independence 
and authority of the Australian Arbitration Commission, the role which the Commission ascribed the ACTU, and what he saw as more politically astute personnel.

Yet, while Sandlant's analysis is insightful in illustrating the importance of the different institutional features of arbitration in post-war Australia and New Zealand, and for its discussion of the role of the ACTU as a support to arbitration, his framework excludes social policy as a factor contributing to the different fates of arbitration in the two countries. Nor does he consider the role of national, non-arbitration minimum standards legislation in New Zealand in shaping the union movement's commitment to arbitration.

Castles $(1985,1996)$ also has little to say on minimum standards legislation. However, as has been discussed previously, a major theme in his wage-earners' welfare state model is the historical trade-off in the two countries between protection through state welfare and protection through arbitration; that is, using his words, between 'wage security' (through arbitration) and 'social security' (through the welfare state) (Castles 1985: 82-88). The working-class strategy more involving the pursuit of the former of these options, formed the basis of the Australasian 'anomaly' (Castles 1985: 10-43). Yet despite the importance he attaches to arbitration, Castles says little on the differing commitment to arbitration by the Australian and New Zealand trade union movements, which became important particularly from the 1960s. And he largely ignores the implications of arbitration for social policy. Instead, he views Australia's stronger embrace of selectivity in welfare, and New Zealand's stronger embrace of welfare generosity, as being mainly due to 'the reciprocal interaction between evolving social policy practice and attitudes to the welfare state' (Castles 1985: 53).

In addition, and of critical importance in relation to the post-war period, Castles eschews employment relations factors, and arbitration and minimum standards legislation in particular, in shaping social protection. This leads to two problems. First, Castles (1996: 102) did not recognise that equal pay in Australia and New Zealand was delivered by different institutional means. And secondly, he ignores the significance of the different features of the two countries' wage-freezes in the lead-up to 
the elections of 1983 in Australia and 1984 in New Zealand. In order to address these deficiencies an alternative account is required.

\section{Union Membership}

When viewed from an international perspective, the period from the late 1940 s to the early 1980 s was characterised more by similarity than difference. Yet the differences, both in policy substance and in the institutional underpinnings of policy, are important in the long historical scheme. In the case of the latter, the differences proved important to the explanation of the major policy cleavages which surfaced in the subsequent period, the 1980s and 1990s.

One of the central considerations is the effectively compulsory basis of union membership in New Zealand, which partially explains the lower level of commitment on the part of the New Zealand trade union movement to the arbitration system. Union membership was not always formally or technically compulsory. Under the 1894 Arbitration Act, unions were allowed to insert unqualified preference clauses in awards, and were highly successful in doing so. From 1936, membership was made legally mandatory for all employees covered by an award. In 1961, the National government diluted the compulsory element by abolishing statutory preference, making it legal only to insert an unqualified preference clause into an award if the affected employer agreed to it. If the union could prove by secret ballot, however, that at least half of the workers covered under an award were in favour of the inclusion of an unqualified preference clause, such a clause was legal. And given that employers often agreed to such clauses regardless, membership was always effectively compulsory (Roth 1973: 101-104; Deeks et al. 1978: 44-45; Sandlant 1989: 48). As argued in the next chapter, in this factor lay an important explanation of why the union movement was so comprehensively divided and conquered by union-hostile employment relations legislation in the early 1990 s.

The important point is not merely that New Zealand unionism was compulsory, but that compulsory unionism often did not carry benefits for workers. Two related factors account for this. Firstly, as argued in 
Chap. 3, compulsory unionism aided the division between industrial and craft unions, a division which by tradition was stronger in New Zealand than it was in Australia. Secondly, as was most clearly demonstrated in the aftermath of the defeat of the unions in 1913 and again in the 1951 waterfront dispute, arbitration-compliant unions could be, and were, formed under the auspices of the compulsory union membership regulations (Roth 1973: 95-104). As was seen, these regulations were used to quash independent, or anti-arbitrationist, unionism (Roth 1973: 104).

\section{Equal Pay, the Wage-Freezes, and the Family Wage Legacy}

Other key indicators of Australia's greater reliance on arbitration as an arm of social protection during the post-War era lay in the equal pay provisions and the wage-freeze regulations. Though both countries implemented a wage-freeze in the early 1980s, which greeted both incoming Labo(u)r governments in 1983 in Australia and 1984 in New Zealand, the freeze in the latter formed part of that government's broader political agenda. In Australia, as discussed, the freeze was implemented by the Arbitration Commission. Though it was the Fraser Coalition government's wish to put a lid on wage claims, without the Commission's approval no freeze could have been implemented. A similar story applies to equal pay (Nieuwenhuysen and Hicks 1975; Ryan and Rowse 1975; Cass 1985; Ryan and Conlon 1975; Whelan 1979; Patmore 1991; Du Plessis 1993; Dann 1985; Koopman-Boyden and Scott 1984). As seen, the New Zealand Arbitration Court washed its hands of equal pay, arguing that it was for the government to introduce.

The other part of this story, however, is told in the relative historical strength of the family wage concept. As found in the current, the formal equalisation of pay between men and women workers formed part of the process of departure from the traditional pattern of social protection in both countries. It made more sense, however, for Australia to shift from a family wage to wages based on gender-equality through the arbitration mechanism, precisely because under the federal Constitution, arbitration was the only channel through which wages policy could be formulated. 
In New Zealand, the family wage was pursued with less certainty by the Arbitration Court. Yet the legislated minimum wage provisions there were family-based in the sense that women were subject to a lower rate than males. Importantly, however, this was set out in legislation, not in arbitration.

\section{The Role of Government}

The question of the relative authority of the arbitration tribunal is closely intertwined with the role of government in employment relations. As found earlier, in New Zealand, particularly from the 1960s to the early 1980s, the government was encouraged to step up its interventionist role in the labour market in the face of increasing recourse by unions and employers to decentralised bargaining. The increased intervention came mainly in the form of measures which reflected government attempts to check the Arbitration Court's loss of authority over the determination of wages and other working conditions. As Boston (1984: 8) argued:

[a]lthough the majority of OECD countries resorted to short-term incomes policies following the rise in global inflation rates in the late 1960s and early 1970s, few have witnessed the degree of state intervention in pay determination as New Zealand, and none ... have experienced such long periods of statutory controls. Between March 1971 and July 1984, for example, mandatory wage controls of one form or another were in force for almost nine years ... Furthermore, of the remaining $41 / 4$ years, only eight months can be legitimately described as a period of free wage bargaining (December 1972-August 1973). During the rest of the time the Government sought by every means short of statutory intervention (moral suasion, political pressure, threats to reintroduce [wage] regulations, the offer of tax cuts, and so forth) to restrain the growth of nominal wages. Such persistence is remarkable, especially when one considers the doubtful effectiveness of many of these efforts.

The regulations put in place by government over the period included the Stabilisation of Remuneration Act of 1971, the Stabilisation of Remuneration Regulations of 1972, the Wage Adjustment Regulations of 1974, the 
Remuneration Act of 1979, and finally, the Wage Freeze Regulations of 1982 (Boston 1984; Walsh 1984; Sandlant 1989: 50). All of them represented the government's quest for increased control over wages.

Yet these instances of increased government intervention were not only due to the prevailing economic conditions. New Zealand governments had other reasons to police wages more closely than did their Australian counterparts. These related to the welfare state, which also contributed to the lower commitment to arbitration in New Zealand. As demonstrated by Castles (1985; 1996; Castles and Shirley 1996; Castles and Mitchell 1992, 1993), the New Zealand welfare state was always at least slightly more comprehensive than the Australian (until the early 1990s). Despite both being labelled as welfare state laggards in the post-war period, universalist principles generally took a firmer hold in New Zealand; even though New Zealand should not be seen as a welfare universalist regime. The most obvious example of this by the 1970s was the universal nature of New Zealand's health care and pensions schemes. Both were administered on a less selective basis than their Australian versions. In Australia, the Fraser government had dismantled the Whitlam government's shortlived universal health scheme, and it did not embrace universality in pension provision. This was true in relation to the vast majority of benefits. Castles largely misses the point, however, that the higher degree of selectivity in Australia was linked with a greater institutional inclination on the part of Australian social protection to rely on arbitration.

\section{The Constitutional Dimension}

Finally, intimately related to questions of arbitration and welfare state provision is the issue of constitutional possibilities. As found in previous chapters, the greater flexibility of the New Zealand Constitution worked in favour of the extension of social protection. This was made most noticeable in the 1930s and 1940s, as discussed in Chap. 3, when the welfare state was being built, and when minimum wage legislation was introduced. The New Zealand Constitution had no effective second chamber, or Upper House. Before the 1950s, it did have one, but it was never as important in practice as the Senate in Australia (Palmer 1987, 
1992; Joseph 1993). Up until mid-1996, when the first election under a new Mixed Member Proportional system was held, New Zealand governments were elected in a first-past-the-post voting system. And the structure of the state was unitary, as opposed to Federal.

\section{Conclusion}

When viewed in international perspective, during the post-war period up to the early 1980s, social protection in New Zealand and Australia developed along similar lines. Having previously established growing welfare states in the 1930s and 1940s, from the 1950s the two regimes made incrementalist advances in the welfare state, and slow and patchy increases in wages through the arbitration system. Formal equal pay came in the 1970 s along with some advances in welfare, but then the two arbitration systems struggled somewhat to regulate the labour market until the beginning of the 1980 s.

Beyond this picture of similarity, Australia adhered more closely to the traditional regime of social protection based on arbitration-dominated employment relations and a welfare state ruled mainly by selectivism. New Zealand faced more challenges to the pattern, with government becoming directly involved in legislating on labour standards and for incomes policies. As in the previous era, the legitimacy of arbitration was more strongly challenged, institutionally and politically, and at times the arbitral system lost control over wage-setting. On the other hand, arbitration in Australia was more independent from government. As the discussion highlighted, this was assisted by the lack of compulsory unionism in Australia, by the lack of a minimum standard-setting process outside of arbitration, and by a union movement that was more reliant on arbitration and less divided in its commitment to it. Hence it was not surprising that equal pay in the 1970s and the wage-freeze of the late 1970s and early 1980s were both established by means of government legislation in New Zealand, and the arbitration system in Australia.

As discussed in the following chapter, these differences were to become more important in the 1980s, as each country ushered in its new Labo(o) ur government. 


\section{References}

Australia, Commission of Inquiry into Poverty. (1975). Poverty in Australia, First Main Report. Canberra: Australian Government Publishing Service.

Bassett, M. (1971). Confrontation '51: The 1951 Waterfront Dispute. Wellington: A.H. and A.W Reed.

Boston, J. (1984). Incomes Policy in New Zealand, 1972-1984. Wellington: Victoria University of Wellington.

Bray, M., \& Haworth, N. (1993). Comparing Australia and New Zealand. In M. Bray \& N. Haworth (Eds.), Economic Restructuring and Industrial Relations in Australia and New Zealand: A Comparative Analysis (Australian Centre for Industrial Relations Research and Teaching Monograph No. 8, ACIRRT) (pp. 1-15). Sydney: University of Sydney.

Bray, M., \& Walsh, P. (1993). Unions and Economic Restructuring in Australia and New Zealand. In M. Bray \& N. Haworth (Eds.), Economic Restructuring and Industrial Relations in Australia and New Zealand: A Comparative Analysis (Australian Centre for Industrial Relations Research and Teaching Monograph, no. 8, ACIRRT) (pp. 122-155). Sydney: University of Sydney.

Bray, M., \& Walsh, P. (1995). Accord and Discord: The Differing Fates of Corporatism Under Labo(u)r Governments in Australia and New Zealand. Labour and Industry: A Journal of the Social and Economic Relations of Work, 6(3), 1-26.

Brosnan, P., \& Rea, D. (1991). An Adequate Minimum Code: A Basis for Freedom, Justice and Efficiency in the Labour Market. New Zealand Journal of Industrial Relations, 16(2), 143-158.

Brosnan, P., Burgess, J., \& Rea, D. (1992). Two Ways to Skin a Cat: Government Policy and Labour Market Reform in Australia and New Zealand. International Contributions to Labour Studies, 2, 17-44.

Bruno, M., \& Sachs, J. D. (1985). Economics of Worldwide Stagflation. Cambridge, MA: Harvard University Press.

Butlin, N. G., Barnard, A., \& Pincus, J. J. (1982). Government and Capitalism: Public and Private Choice in Twentieth Century Australia. Sydney: Allen and Unwin.

Calmfors, L., \& Driffill, J. (1988, April). Bargaining Structure, Corporatism and Macroeconomic Performance. Economic Policy, 13-61.

Carney, S., \& Hanks, P. (1994). Social Security in Australia. Oxford: Oxford University Press. 
Cass, B. (1983). Redistribution to Children and to Mothers: A History of Child Endowment and Family Allowances. In C. V. Baldock \& B. Cass (Eds.), Women, Social Welfare and the State in Australia (pp. 54-84). Sydney: Allen and Unwin.

Cass, B. (1985). Rewards for Women's Work. In J. Goodnow \& C. Pateman (Eds.), Women, Social Science and Public Policy (pp. 67-94). Sydney: Allen and Unwin.

Cass, B., \& Whiteford, P. (1989). Social Security Policies. In B. Head \& A. Patience (Eds.), From Fraser to Hawke: Australian Public Policy in the 1980's (pp. 273-303). Sydney: Longman Cheshire.

Castles, F. G. (1985). The Working Class and Welfare: Reflections on the Political Development of the Welfare State in Australia and New Zealand, 1890-1980. Wellington/Sydney: Allen and Unwin.

Castles, F. G. (1996). Needs-based Strategies of Social Protection in Australia and New Zealand. In G. Esping-Andersen (Ed.), Welfare States in Transition: National Adaptations in Global Economies (pp. 88-115). London: SAGE Publications.

Castles, F. G., \& Mitchell, D. (1992). Identifying Welfare State Regimes: The Links Between Politics, Instruments and Outcomes. Governance, 5(1), 1-26. Castles, F. G., \& Mitchell, D. (1993). Worlds of Welfare and Families of Nations. In F. G. Castles (Ed.), Families of Nations: Patterns of Public Policy in Western Democracies (pp. 93-128). Aldershot: Dartmouth.

Castles, F. G., \& Shirley, I. F. (1996). Labour and Social Policy: Gravediggers or Refurbishers of the Welfare State? In F. G. Castles, R. Gerritsen, \& J. Vowles (Eds.), The Great Experiment: Labour Parties and Public Policy Transformation in Australia and New Zealand (pp. 88-100). Sydney: Allen and Unwin.

Dabscheck, B. (1989). Australian Industrial Relations in the 1980's. Melbourne: Oxford University Press.

Dabscheck, B. (1994). The Arbitration System Since 1967. In S. Bell \& B. Head (Eds.), State, Economy and Public Policy in Australia (pp. 142-168). Melbourne: Oxford University Press.

Dabscheck, B., \& Niland, J. (1981). Industrial Relations in Australia. Sydney: Allen and Unwin.

Chapman, R. (1981). From Labour to National. In W. H. Oliver \& B. R. Williams (Eds.), The Oxford History of New Zealand (pp. 333-368). Oxford: Clarendon Press.

Dann, C. (1985). Up From Under: Women and Liberation in New Zealand, 1970-1985. Wellington: Allen and Unwin. 
Davey, P. (1978). Financing of Education. In R. B. Scotton \& H. Ferber (Eds.), Public Expenditures and Social Policy in Australia: Volume I; The Whitlam Years, 1972-75 (pp. 38-86). Melbourne: Longman Cheshire.

Davidson, A. (1989). Two Models of Welfare: The Origins and Development of the Welfare State in Sweden and New Zealand, 1888-1988. Uppsala: Acta Universitatis Upsaliensis.

Deeks, J., Roth, H., Farmer, J., \& Scott, G. (1978). Industrial Relations in New Zealand. Wellington: Methuen New Zealand.

Du Plessis, R. (1993). Women, Politics, and the State. In B. Roper \& C. Rudd (Eds.), State and Economy in New Zealand (pp. 210-225). Oxford: Oxford University Press.

Dyster, B., \& Meredith, D. (1990). Australia in the International Economy in the Twentieth Century. Cambridge: Cambridge University Press.

Easton, B. (1981). Pragmatism and Progress: Social Security in the Seventies. Christchurch: University of Canterbury.

Esping-Andersen, G. (1990). The Three Worlds of Welfare Capitalism. Cambridge: Polity Press.

Freeman, R. B. (1988, April). Labour Market Institutions and Economic Performance. Economic Policy, 63-80.

Gauthier, A. H. (1996). The State and the Family: A Comparative Analysis of Family Policies in Industrialised Countries. Oxford: Clarendon Press.

Gollan, R. (1968). The Historical Perspective. In P. W. D. Matthews \& G. W. Ford (Eds.), Australian Trade Unions: Their Development, Structure and Horizons (pp. 14-40). Melbourne: Sun Books.

Graycar, A. (1979). Welfare Politics in Australia: A Study in Policy Analysis. Melbourne: Macmillan.

Hancock, K. J. (1979). The First Half-Century of Wage Policy - Part II. Journal of Industrial Relations, 21(2), 129-160.

Hanson, E. (1980). The Politics of Social Security: The 1938 Act and Some Later Developments. Auckland: Auckland University Press.

Henderson, R. F., Harcourt, A., \& Harper, R. J. A. (1970). People in Poverty: A Melbourne Survey. Melbourne: Cheshire.

Hutson, J. (1971). Six Wage Concepts. Sydney: Amalgamated Engineering Union. Isaac, J. E. (1986). The Meaning and Significance of Comparative Wage Justice. In J. Niland (Ed.), Wage Fixation in Australia (pp. 84-104). Sydney: Allen and Unwin.

Joseph, P. A. (1993). Constitutional and Administrative Law in New Zealand. Sydney: The Law Book Company Ltd.. 
Kewley, T. H. (1973). Social Security in Australia, 1900-72. Sydney: Sydney University Press.

Koopman-Boyden, P., \& Scott, C. (1984). The Family and Government Policy in New Zealand. Sydney: Allen and Unwin.

Laffer, K. (1964). The Total Wage. Journal of Industrial Relations, 6(2), 72-78. Lake, M. (1992). The Independence of Women and the Brotherhood of Man: Debates in the Labour Movement Over Equal Pay and Motherhood Endowment in the 1920s. Labour History: A Journal of Labour and Social History, (63), 1-24.

Lewis, M. T. (1975). Values in Australian Income Security Policies. Canberra: Australian Government Publishing Service.

Macnicol, J. (1992). Welfare, Wages and the Family: Child Endowment in Comparative Perspective, 1900-1950. In R. Cooter (Ed.), In the Name of the Child: Health and Welfare, 1880-1940 (pp. 244-275). London: Routledge.

Mendelsohn, R. (1979). The Condition of the People: Social Welfare in Australia, 1900-1975. Sydney: Allen and Unwin.

New Zealand, Royal Commission on Social Security. (1972). Social Security in New Zealand: Report of the Royal Commission of Inquiry. Wellington: Government Printer.

Nieuwenhuysen, J., \& Hicks, J. (1975). Equal Pay for Women in Australia and New Zealand. In B. O. Pettmann (Ed.), Equal Pay for Women: Progress and Problems in Seven Countries (pp. 63-97). Bradford: MCB Books.

Palmer, G. (1987). Unbridled Power: An Interpretation of New Zealand's Constitution and Government. Auckland: Oxford University Press.

Palmer, G. (1989). Health Insurance and Financing. In B. W. Head \& A. Patience (Eds.), From Fraser to Hawke: Australian Public Policy in the 1980's (pp. 324-346). Melbourne: Longman Cheshire.

Palmer, G. (1992). New Zealand's Constitution in Crisis: Reforming our Political System. Dunedin: John McIndoe.

Patmore, G. (1991). Australian Labour History. Sydney: Longman Cheshire.

Provis, C. (1986). Comparative Wage Justice. Journal of Industrial Relations, 28(1), 24-39.

Roth, H. (1973). Trade Unions in New Zealand: Past and Present. Wellington: Reed Foundation.

Roth, H. (1986). The New Zealand Trade Union Congress, 1950-51. In E. Fry (Ed.), Common Cause: Essays in Australian and New Zealand Labour History (pp. 124-138). Wellington: Allen and Unwin. 
Rudd, C. (1993). The New Zealand Welfare State: Origins, Development, and Crisis. In B. Roper \& C. Rudd (Eds.), State and Economy in New Zealand (pp. 226-245). Oxford: Oxford University Press.

Ryan, E., \& Conlon, A. (1975). Gentle Invaders: Australian Women at Work, 1788-1974. Melbourne: Nelson.

Ryan, E., \& Rowse, T. (1975). Women, Arbitration and the Family. In A. Curthoys, S. Eade, \& P. Spearritt (Eds.), Women at Work (pp. 15-30). Canberra: Australian Society for the Study of Labour History.

Sandlant, R. (1988). "Strategic Unionism": The Australian and New Zealand Trade Union Movements and Economic Liberalisation. Paper Presented at the Conference of the Australasian Political Studies Association, University of New England, Armidale.

Sandlant, R. A. (1989). The Political Economy of Wage Restraint: The Australian Accord and Trade Union Strategy in New Zealand. Unpublished MA Thesis, Department of Political Studies, University of Auckland, Auckland.

Scott, D. (1952). 151 Days: History of the Great Waterfront Lockout and Supporting Strikes. Auckland: New Zealand Waterside Workers' Union.

Scotton, R. B. (1978). Public Expenditures and Social Policy. In R. B. Scotton \& H. Ferber (Eds.), Public Expenditures and Social Policy in Australia: Volume I; The Whitlam Years, 1972-75 (pp. 1-37). Melbourne: Longman Cheshire.

Shaver, S. (1990). Gender, Social Policy Regimes and the Welfare State (Social Policy Research Centre Discussion Paper No. 26). Sydney: University of New South Wales, Social Policy Research Centre.

Stewart, G. (1995). Making People in Poverty a Policy Issue: A Case Study in Policy Initiation. Unpublished PhD Thesis, School of Social Science and Policy, University of New South Wales, Sydney.

Sutch, W. B. (1966). The Quest for Security in New Zealand, 1840 to 1966. Wellington: Oxford University Press.

Sutch, W. B. (1971). The Responsible Society in New Zealand. Whitcombe and Tombs Ltd., Christchurch.

Taylor-Gooby, P. (1991). Welfare State Regimes and Welfare Citizenship. Journal of European Social Policy, 1(2), 92-105.

Townsend, P. (1962). The Meaning of Poverty. British Journal of Sociology, 13(3), 210-227.

Townsend, P. (1979). Poverty in the United Kingdom: A Survey of Household Resources and Standards of Living. Harmondsworth: Penguin Books.

Turner, I. (1976). In Union is Strength: A History of Trade Unionism in Australia, 1788-1974. Melbourne: Nelson. 
Wailes, N. (1997). The (Re)discovery of the Individual Employment Contract in Australia and New Zealand: The Changing Demands on Industrial Relations Institutions in a Period of Economic Restructuring. In A. Frazer, R. McCallum, \& P. Ronfeldt (Eds.), Individual Contracts and Workplace Relations (Australian Centre for Industrial Relations Research and Training (ACIRRT) Working Paper No. 50, ACIRRT) (pp. 23-54). Sydney: University of Sydney.

Walsh, P. (1984). The Rejection of Corporatism: Trade Unions, Employers and the State in New Zealand, 1960-1977. Unpublished PhD Thesis, Department of Political Science, University of Minnesota.

Walsh, P. (1993). The State and Industrial Relations in New Zealand. In B. Roper \& C. Rudd (Eds.), State and Economy in New Zealand (pp. 172-191). Oxford: Oxford University Press.

Walsh, P. (1994). An "Unholy Alliance": The 1968 Nil Wage Order. New Zealand Journal of History, 28(2), 178-193.

Watts, R. (1987). The Foundations of the National Welfare State. Sydney: Allen and Unwin.

Watts, R. (1989). In Fractured Times': The Accord and Social Policy Under Hawke, 1983-87. In R. Kennedy (Ed.), Australian Welfare: Historical Sociology (pp. 104-131). Melbourne: Macmillan.

Whelan, D. (1979). Women and the Arbitration System. Journal of Australian Political Economy, 4, 54-60.

Woods, N. S. (1963). Industrial Conciliation and Arbitration in New Zealand. Wellington: R.E. Owen, Government Printer.

Open Access This chapter is licensed under the terms of the Creative Commons Attribution 4.0 International License (http://creativecommons.org/licenses/ by/4.0/), which permits use, sharing, adaptation, distribution and reproduction in any medium or format, as long as you give appropriate credit to the original author(s) and the source, provide a link to the Creative Commons licence and indicate if changes were made.

The images or other third party material in this chapter are included in the chapter's Creative Commons licence, unless indicated otherwise in a credit line to the material. If material is not included in the chapter's Creative Commons licence and your intended use is not permitted by statutory regulation or exceeds the permitted use, you will need to obtain permission directly from the copyright holder.

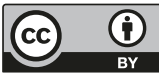

